\section{A novel oxidative transformation of alcohols to nitriles: an efficient utility of azides as a nitrogen source $\dagger$}

\author{
Balaji V. Rokade, Sanjeev K. Malekar and Kandikere Ramaiah Prabhu* \\ Received 20th February 2012, Accepted 11th April 2012 \\ DOI: $10.1039 / \mathrm{c} 2 \mathrm{cc} 31256 \mathrm{e}$
}

An efficient methodology to oxidize benzylic and cinnamyl alcohols to their corresponding nitriles in excellent yields has been developed. This methodology employs DDQ as an oxidant and $\mathrm{TMSN}_{3}$ as a source of nitrogen in the presence of a catalytic amount of $\mathrm{Cu}\left(\mathrm{ClO}_{4}\right)_{2} \cdot 6 \mathrm{H}_{2} \mathrm{O}$.

The azide functionality is one of the valuable intermediates in organic synthesis. ${ }^{1}$ Utility of azides ${ }^{2 a-c}$ is demonstrated in insertion of nitrogen into hydrocarbons to obtain tetrazoles, ${ }^{2 d}$ amides $^{2 e}$ or transform allylarenes to alkenyl nitriles ${ }^{2 f, g}$ and in click chemistry. ${ }^{3}$ Ammonia or its alternatives have been used as the source of nitrogen to synthesize amines, amides, nitriles etc., ${ }^{4}$ which require harsh conditions such as high pressure and/or temperature. Nevertheless, these reactions have paved new avenues of utility of azides in the synthesis of nitrogencontaining heterocyclic compounds by $\mathrm{C}-\mathrm{H}$ or $\mathrm{C}-\mathrm{C}$ bond cleavage. ${ }^{5}$ The nitrile functionality is special in organic synthesis ${ }^{6}$ as it occurs in several natural products ${ }^{7}$ and can be transformed into a variety of functional groups such as amines, ketones, acids, amides etc. Aliphatic nitriles are synthesized using corresponding halides and metal cyanides, ${ }^{8}$ whereas aromatic nitriles are synthesized by employing the classical Sandmeyer reaction..$^{9}$ Dehydration of amides, ${ }^{10}$ oximes $^{11}$ and oxidative conversion of alcohols ${ }^{12}$ or amines ${ }^{13}$ are a few more methods reported to accomplish synthesis of nitriles. $\mathrm{C}-\mathrm{H}$ functionalization of methyl arenes to corresponding nitriles has been reported by Jiao and co-workers, ${ }^{14}$ which requires activated precursors. The utility of azides to synthesize aryl, alkyl or alkenyl nitriles has been reported by various groups. ${ }^{2,15}$ Interestingly, DDQ (2,3-dichloro-5,6-dicyano-1,4-benzoquinone) is known to oxidize cinnamyl azide to cinnamonitrile. ${ }^{2 f, g}$ Further, azides are easily accessed by azidation of either allylic alcohols ${ }^{2 h}$ or allylic acetates. ${ }^{2 i}$ As alcohols are inexpensive and easily available or prepared, it is advantageous to synthesize nitriles directly from alcohols. It is important to note that most of the methods for synthesizing nitriles employ halides, acetates or azides, which are generally obtained from their corresponding alcohols.

Department of Organic chemistry, Indian Institute of Science, Bangalore 560 012, Karnataka, India.

E-mail:prabhu@orgchem.iisc.ernet.in; Fax: +91-80-23600529

$\dagger$ Electronic supplementary information (ESI) available: Experimental procedures, characterization data, and NMR spectra for all products. See DOI: $10.1039 / \mathrm{c} 2 \mathrm{cc} 31256 \mathrm{e}$
Attempts in this direction to synthesize nitriles directly from alcohols $^{12}$ require forcing conditions. ${ }^{16}$ Recently, we have reported the transformation of benzylic azides to nitriles using $\mathrm{CuI}$ and TBHP (tert-butyl hydroperoxide). ${ }^{17}$ In continuation of our investigation, ${ }^{18}$ herein we report an elegant strategy to transform cinnamyl and benzyl alcohols to their corresponding nitriles using $\mathrm{TMSN}_{3}$ (trimethylsilyl azide) as a nitrogen source with a catalytic amount of $\mathrm{Cu}\left(\mathrm{ClO}_{4}\right)_{2} \cdot 6 \mathrm{H}_{2} \mathrm{O}$ in the presence of DDQ.

Initial optimization studies were carried out using cinnamyl alcohol (1a) and $\mathrm{Cu}\left(\mathrm{ClO}_{4}\right)_{2} \cdot 6 \mathrm{H}_{2} \mathrm{O}$ with a variety of oxidants (Table 1). Preliminary experiments indicated that $\mathrm{TMSN}_{3}$ is a suitable source of nitrogen under the present reaction conditions. Contrary to our expectation sodium azide $\left(\mathrm{NaN}_{3}\right)$ did not furnish the desired product. ${ }^{19}$ Therefore, further studies were carried out using TMSN $3, \mathrm{Cu}\left(\mathrm{ClO}_{4}\right)_{2} \cdot 6 \mathrm{H}_{2} \mathrm{O}$ and a variety of oxidants (Table 1). Interestingly, atmospheric air or molecular oxygen as oxidants furnished the corresponding azide $\mathbf{3} \mathbf{a}$ as the major product (entries 1 and 2, Table 1), whereas, a similar reaction with $\mathrm{H}_{2} \mathrm{O}_{2}$ was unsuccessful (entry 3). Reaction of cinnamyl alcohol 1a with TBHP, benzoquinone, di-tert-butyl peroxide (DTBP), or chloranil resulted in the formation of a

Table 1 Optimization studies of oxidants ${ }^{a}$

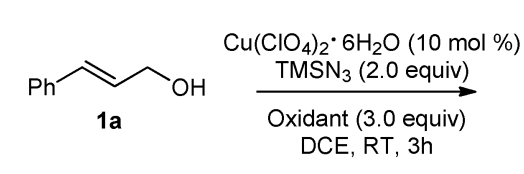

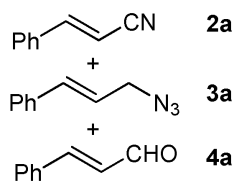

\begin{tabular}{llllll}
\hline & & \multicolumn{4}{l}{ Yield $^{b}(\%)$} \\
\cline { 3 - 6 } Entry & Oxidant & 2a & 3a & 4a & 1a \\
\hline 1 & Air & nd & 95 & nd & nd \\
2 & $\mathrm{O}_{2}$ & nd & 75 & nd & 25 \\
3 & $\mathrm{H}_{2} \mathrm{O}_{2}$ & nd & nd & nd & 100 \\
4 & Aq. TBHP $(70 \%)$ & nd & 52 & 5 & 43 \\
5 & TBHP in decane & Inseparable mixture & \\
6 & Benzoquinone & Inseparable mixture & \\
7 & DTBP & nd & 42 & nd & 58 \\
8 & Chloranil & 32 & 14 & 54 & nd \\
$\mathbf{9}$ & DDQ & $\mathbf{1 0 0}$ & nd & nd & nd \\
$\mathbf{1 0}^{c}$ & DDQ & $\mathbf{1 0 0}$ & nd & nd & nd
\end{tabular}

${ }^{a}$ Reaction conditions: alcohol $(0.50 \mathrm{mmol}), \mathrm{TMSN}_{3}(1.0 \mathrm{mmol})$, $\mathrm{Cu}\left(\mathrm{ClO}_{4}\right)_{2} \cdot 6 \mathrm{H}_{2} \mathrm{O}(0.05 \mathrm{mmol})$, oxidant $(1.5 \mathrm{mmol}), 1,2$-dichloroethane ( $2 \mathrm{ml})$, RT. ${ }^{b}$ Yields were determined by ${ }^{1} \mathrm{H}$ NMR analysis with respect to the starting material. ${ }^{c}$ Reaction carried out at $60{ }^{\circ} \mathrm{C}$ for $1 \mathrm{~h}$. nd $=$ not detected $(<1 \%)$. 
Table 2 Catalyst screening

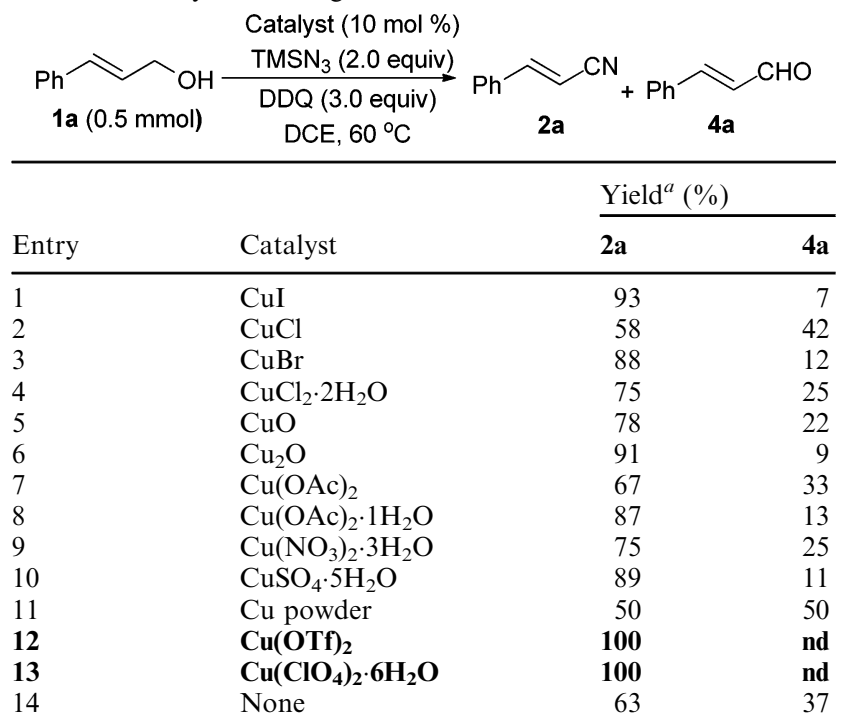

${ }^{a}$ Yields were determined by ${ }^{1} \mathrm{H}$ NMR with respect to the starting material. nd $=$ not detected $(<1 \%)$.

mixture of products (entries 4-8, Table 1). Finally, it was satisfying to find that a catalytic amount of $\mathrm{Cu}\left(\mathrm{ClO}_{4}\right)_{2} \cdot 6 \mathrm{H}_{2} \mathrm{O}$ and $\mathrm{TMSN}_{3}$ in the presence of DDQ was a suitable system to transform cinnamyl alcohol $\mathbf{1 a}$ to cinnamonitrile $\mathbf{2 a}$ at room temperature in almost quantitative yield ( $3 \mathrm{~h}$, entry 9 , Table 1$)$. Further, it was found that the same reaction proceeds well at $60{ }^{\circ} \mathrm{C}$ in shorter duration $(1 \mathrm{~h})$ to furnish cinnamonitrile $2 \mathrm{a}$ in quantitative yield (entry 10, Table 1).

Further studies revealed that copper catalysts such as copper halides, copper oxides, copper acetate, copper nitrate, copper sulphate and copper powder under the identical reaction conditions are not suitable catalysts as they resulted in the formation of mixtures of corresponding nitriles and aldehydes (entries 1-11, Table 2). However, $\mathrm{Cu}(\mathrm{OTf})_{2}$ and $\mathrm{Cu}\left(\mathrm{ClO}_{4}\right)_{2} \cdot 6 \mathrm{H}_{2} \mathrm{O}$ were found to be the most suitable catalysts, as these reactions furnished the quantitative yield of 2a (entries 12 and 13, Table 2). The reaction also proceeded in the absence of copper catalysts but unfortunately furnished the mixture of corresponding nitrile and aldehyde (entry 14, Table 2). In the solvent screening studies, it was found that dichloroethane (DCE), toluene and $\mathrm{CH}_{3} \mathrm{CN}$ were suitable solvents for conversion of alcohol 1a to the corresponding nitrile $\mathbf{2 a}$, whereas the reaction in THF resulted in lower yield of the product. No reaction was observed in $\mathrm{MeOH}$ or water as solvent (see Table $\mathrm{S} 1$ in ESI $\dagger$ ). With the help of additional screening studies (Table S2, ESI $\dagger$ ), it was found that $5 \mathrm{~mol} \% \mathrm{Cu}\left(\mathrm{ClO}_{4}\right)_{2} \cdot 6 \mathrm{H}_{2} \mathrm{O}, 1.5$ equiv. $\mathrm{TMSN}_{3}$, and 2.2 equiv. of DDQ are required for the efficient conversion of cinnamyl alcohol 1a to cinnamonitrile $\mathbf{2 a}{ }^{20}$

Under the optimized reaction conditions, the scope and limitation of the reaction was investigated and the results have been compiled in Table 3. As can be seen in Table 3, a variety of substituted cinnamyl alcohols were converted to their corresponding nitriles in excellent yields. It is evident from the table that neither electron-donating substituents nor electronwithdrawing substituents have any effect on the outcome of the reaction and the reaction proceeded well to furnish
Table 3 Conversion of cinnamyl alcohols to nitriles ${ }^{a, b}$
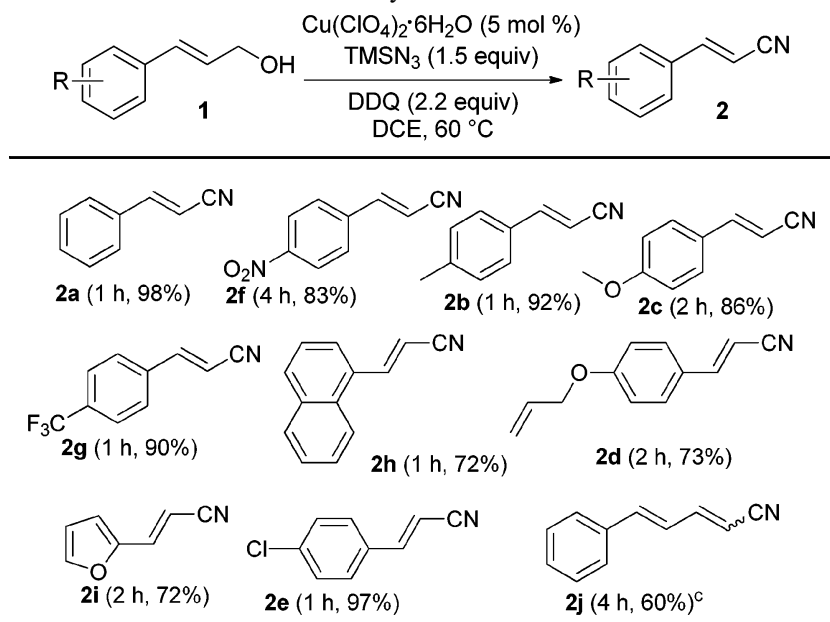

${ }^{a}$ Reaction conditions: $\mathrm{TMSN}_{3}(0.75 \mathrm{mmol})$, alcohol $(0.5 \mathrm{mmol})$, $\mathrm{Cu}\left(\mathrm{ClO}_{4}\right)_{2} \cdot 6 \mathrm{H}_{2} \mathrm{O}(0.025 \mathrm{mmol})$, DDQ $(1.1 \mathrm{mmol})$ in DCE $(2 \mathrm{~mL})$ at $60{ }^{\circ} \mathrm{C} .{ }^{b}$ Isolated yields. ${ }^{c}$ Mixture of $E$ and $\mathrm{Z}$ diastereomers (8.9: 1.1, based on $\left.{ }^{1} \mathrm{HNMR}\right)$.

the corresponding nitriles $\mathbf{2 a}, \mathbf{2 b}, \mathbf{2 c}, \mathbf{2 d}, \mathbf{2 e}, \mathbf{2 f}, \mathbf{2 g}, \mathbf{2 h}, \mathbf{2 i}$ and $\mathbf{2} \mathbf{j}^{21}$ respectively, in good to excellent yields (Table 3 ).

To extend the scope of this reaction, a variety of benzylic alcohols were subjected to similar reaction conditions (Table 4). As seen in the table, this method is proved to be versatile as a variety of benzylic alcohols with electron-withdrawing and electron-donating substituents on the phenyl ring were converted to their corresponding nitriles (6a-6s) in good yields. However, 2-phenylethanol did not produce the corresponding nitrile, which may be due to the lack of conjugation (6t, Table 4). The salient feature of the above reaction is that this transformation is selective as a variety of functional groups such as allylic, propargylic, $O$-benzylic, ester groups, which are prone to oxidation, were inert under the reaction conditions. Additionally, the reaction tolerates the protecting groups such as TBDPS, TBDMS and benzylic which are prone to undergo deprotection under milder reaction conditions.

Based on a few control experiments (see Scheme S1, ESI $\dagger$ ) and literature precedence, ${ }^{22-24}$ we believe that $\mathrm{Cu}\left(\mathrm{ClO}_{4}\right)_{2} \cdot 6 \mathrm{H}_{2} \mathrm{O}$, which is a Lewis acid, activates the alcohol (or aldehyde) and assists the nucleophilic attack of $\mathrm{TMSN}_{3}$ to form the corresponding azide, which further reacts with DDQ to form allylic or benzylic carbocation $\mathbf{I}$, which furnishes the corresponding nitrile as presented in Scheme 1. Further work is underway in our laboratory.

In conclusion, we have demonstrated a novel, efficient and useful methodology to oxidize benzylic and cinnamyl alcohols to their corresponding nitriles in excellent yields by employing DDQ as an oxidant and $\mathrm{TMSN}_{3}$ as a source of nitrogen in the presence of a catalytic amount of $\mathrm{Cu}\left(\mathrm{ClO}_{4}\right)_{2} \cdot 6 \mathrm{H}_{2} \mathrm{O}$. Further, this method tolerates a variety of oxidizable functional groups and a few useful protecting groups. Additionally, it was also observed that cinnamyl azide can be synthesized using cinnamyl alcohol, $\mathrm{TMSN}_{3}$ and $\mathrm{Cu}\left(\mathrm{ClO}_{4}\right)_{2} \cdot 6 \mathrm{H}_{2} \mathrm{O}$ which is also under investigation.

We are grateful to Indian Institute of Science, CSIR, New Delhi (no. 01(2415)/10/EMR-II), for financial assistance, and Dr A. R. Ramesha for useful discussions. BVR thanks CSIR, New Delhi, for a research fellowship. 
Table 4 Conversion of benzylic alcohols to nitriles ${ }^{a, b}$

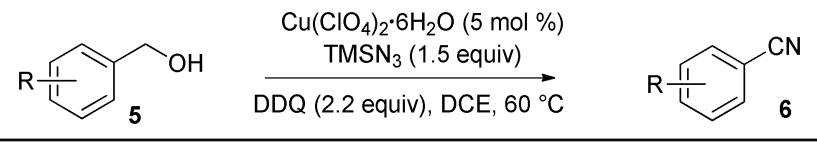

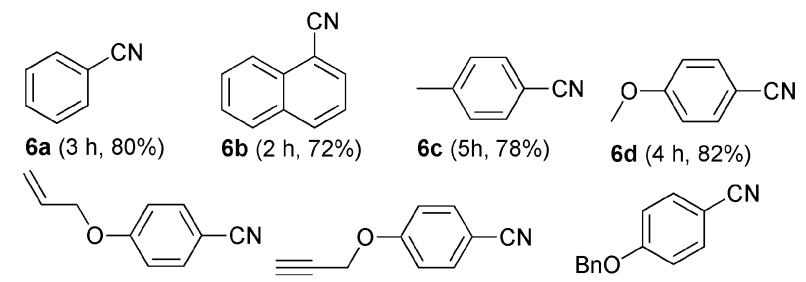

$6 e(1 \mathrm{~h}, 82 \%)$

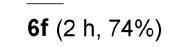

$6 \mathrm{~g}(8 \mathrm{~h}, 96 \%)$<smiles>N#Cc1ccc(-c2ccccc2)cc1</smiles><smiles>N#Cc1ccc(Cl)cc1</smiles>
6j $(8 \mathrm{~h}, 98 \%)$

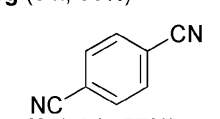

$6 \mathbf{k}(10 \mathrm{~h}, 77 \%)$<smiles>COC(=O)c1ccc(C#N)cc1</smiles><smiles>COC(=O)/C=C/c1ccc(C#N)cc1</smiles><smiles>CCN(CC)C(=O)c1ccc(C#N)cc1</smiles><smiles>N#Cc1ccc([N+](=O)[O-])cc1</smiles>

$6 \mathbf{r}(10 \mathrm{~h}, 95 \%)$<smiles>CCCCOc1ccc(C#N)cc1</smiles>

$6 \mathrm{p}(1 \mathrm{~h}, 98 \%)$<smiles>N#Cc1c[nH]c2ccccc12</smiles>

6s $(4 \mathrm{~h}, 72 \%)$ 6n $(20 \mathrm{~h}, 73 \%)$

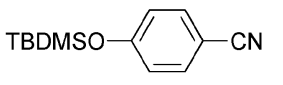

$6 q(2 \mathrm{~h}, 90 \%)$

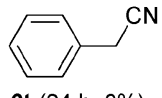

6t $(24 \mathrm{~h}, 0 \%)$
${ }^{a}$ Reaction conditions: $\mathrm{TMSN}_{3}(0.75 \mathrm{mmol})$, alcohol $(0.5 \mathrm{mmol})$, $\mathrm{Cu}\left(\mathrm{ClO}_{4}\right)_{2} \cdot 6 \mathrm{H}_{2} \mathrm{O}(0.025 \mathrm{mmol})$, DDQ $(1.1 \mathrm{mmol})$ in DCE $(2 \mathrm{~mL})$ at $60{ }^{\circ} \mathrm{C} .{ }^{b}$ Isolated yields.

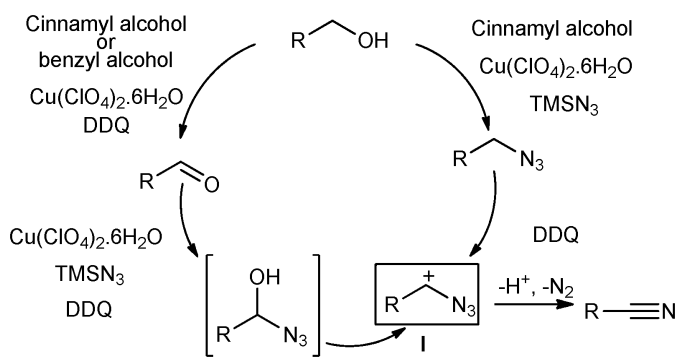

Scheme 1 A tentative mechanism.

\section{Notes and references}

1 (a) E. F. V. Scriven and K. Turnbull, Chem. Rev., 1988, 88, 297; (b) V. V. Rostovtsev, L. G. Green, V. V. Fokin and K. B. Sharpless, Angew. Chem., Int. Ed., 2002, 41, 2596; (c) S. Brase, C. Gil, K. Knepper and V. Zimmermann, Angew. Chem., Int. Ed., 2005, 44, 5188; (d) S. Lang and J. Murphy, Chem. Soc. Rev., 2006, 35, 146; (e) E. Leemans, M. D'Hooghe and N. D. Kimpe, Chem. Rev., 2011, 111, 3268; $(f)$ T. Pasinszki, M. Krebsz and O. Wagner, Curr. Org. Chem., 2011, 15, 1700.

2 (a) W. Q. Tian and Y. A. Wang, J. Org. Chem., 2004, 69, 4299; (b) F. L. Lin, H. M. Hoyt, H. V. Halbeek, R. G. Bergman and C. R. Bertozzi, J. Am. Chem. Soc., 2005, 127, 2686; (c) E. Arstad, A. G. M. Barrett, B. T. Hopkins and J. Kobberling, Org. Lett., 2002, 4, 1975; (d) C. Qin, W. Zhou, F. Chen, Y. Ou and N. Jiao, Angew. Chem., Int. Ed., 2011, 50, 12595; (e) F. Chen, C. Qin, Y. Cui and N. Jiao, Angew. Chem., Int. Ed., 2011, 50, 11487; $(f)$ C. Qin and N. Jiao, J. Am. Chem. Soc., 2010, 132, 15893; (g) W. Zhou, J. Xu,

L. Zhang and N. Jiao, Org. Lett., 2010, 12, 2888; (h) M. Rueping, C. Vila and U. Uria, Org. Lett., 2012, 14, 768; (i) B. Sreedhar, P. S. Reddy and N. S. Kumar, Tetrahedron Lett., 2006, 47, 3055.

3 (a) L. Ackermann and H. K. Potukuchi, Org. Biomol. Chem., 2010, 8, 4503; (b) J. E. Hein and V. V. Fokin, Chem. Soc. Rev., 2010, 39, 1302.

4 J. L. Klinkenberg and J. F. Hartwig, Angew. Chem., Int. Ed., 2011 50, 86.

5 K. Banert, The Chemistry of Vinyl, Allenyl, and Ethynyl Azides, in Organic Azides - Syntheses and Applications, ed. S. Bräse and K. Banert, John Wiley \& Sons Ltd., Chichester, 2010, pp. 115-166.

6 (a) The Chemistry of the Cyano Group, ed. Z. Rappoport, Interscience, New York, 1970; (b) S. Arseniyadis, K. S. Kyler and D. S. Watt, in Organic Reactions, ed. W. G. Dauben, Wiley, New York, 1984, vol. 31, pp. 1-374; (c) A. J. Fatiadi, in Preparation and Synthetic Applications of Cyano Compounds, ed. S. Patai and Z. Rappaport, Wiley, New York, 1983; (d) R. C. Larock, Comprehensive Organic Transformations, VCH, New York, 1989; (e) J. S. Miller and J. L. Manson, Acc. Chem. Res., 2001, 34, 563.

7 (a) R. C. Larock, Comprehensive Organic Transformations, VCH, Weinheim, 1989, p. 819; (b) C. Grundmann, in Houben-Weyl: Methoden der organischenChemie, ed. J. Falbe, Thieme, Stuttgart, 4th edn, 1985, vol. E5, p. 1313.

8 (a) M. Sundermeier, A. Zapf and M. Beller, Chem. Commun., 2004, 1388; (b) H.-J. Cristau, A. Ouali, J.-F. Spindler and M. Taillefer, Chem.-Eur. J., 2005, 11, 2483; (c) J. Zanon, A. Klapars and S. L. Buchwald, J. Am. Chem. Soc., 2003, 125, 2890.

9 T. Sandmeyer, Ber. Dtsch. Chem. Ges., 1885, 18, 1946.

10 (a) C.-W. Kuo, J.-L. Zhu, J.-D. Wu, C.-M. Chu, C.-F. Yao and K.-S. Shia, Chem. Commun., 2007, 301; (b) K. Mai and G. Patil, Tetrahedron Lett., 1986, 27, 2203; (c) S. Enthaler, Chem.-Eur. J., 2011, 17, 9316.

11 (a) E. Choi, C. Lee, Y. Na and S. Chang, Org. Lett., 2002, 4, 2369; (b) K. Yamaguchi, H. Fujiwara, Y. Ogasawara, M. Kotani and N. Mizuno, Angew. Chem., Int. Ed., 2007, 46, 3922.

12 (a) S. Iida and H. Togo, Tetrahedron, 2007, 63, 8274; (b) N. Mori and H. Togo, Synlett, 2005, 1456; (c) S. Iida and H. Tago, Synlett, 2007, 407; (d) S. Yamazaki and Y. Yamazaki, Chem. Lett., 1990, 571; (e) G. D. McAllister, C. D. Wilfred and R. J. K. Taylor, Synlett, 2002, 1291; ( $f$ ) F.-E. Chen, Y.-Y. Li and H.-Q. Jia, Synthesis, 2002, 1804.

13 (a) H. Veisi, Synthesis, 2010, 2631; (b) C. Zhu, C. Sun and Y. Wei, Synthesis, 2010, 4235.

14 W. Zhou, L. Zhang and N. Jiao, Angew. Chem., Int. Ed., 2009, 48, 7094.

15 (a) R. Sasson and S. Rozen, Org. Lett., 2005, 7, 2177; (b) S. Chiba, L. Zhang, G. Y. Ang and B. W.-Q. Hui, Org. Lett., 2010, 12, 2052; (c) W. Zhou, J. Xu, L. Zhang and N. Jiao, Synlett, 2011, 887; (d) J. He, K. Yamaguchi and N. Mizuno, J. Org. Chem., 2011, 76, 4606; (e) R. Hernandez, E. I. Leon, P. Moreno, R. F. Concepcion and E. Suarez, J. Org. Chem., 2004, 69, 8437; $(f)$ H. Hayashi, A. Ohno and S. Oka, Bull. Chem. Soc. Jpn., 1976, 49, 506.

16 (a) T. Oishi, K. Yamaguchi and N. Mizuno, Angew. Chem., Int. Ed., 2009, 48, 6286; (b) T. Oishi, K. Yamaguchi and N. Mizuno, Top. Catal., 2010, 53, 479.

17 M. Lamani and K. R. Prabhu, Angew. Chem., Int. Ed., 2010, 49, 6622

18 (a) M. Maddani and K. R. Prabhu, Tetrahedron Lett., 2008, 49, 4526; (b) M. Maddani, S. R. K. Moorthy and K. R. Prabhu, Tetrahedron, 2010, 66, 329; (c) M. Maddani and K. R. Prabhu, J. Chem. Sci., 2010, 90, 287; (d) K. Alagiri and K. R. Prabhu, Tetrahedron, 2011, 67, 8544; (e) M. Lamani, P. Devadig and K. R. Prabhu, Org. Biomol. Chem., 2012, 10, 2753.

19 The reaction of cinnamyl alcohol with $\mathrm{Cu}\left(\mathrm{ClO}_{4}\right)_{2} \cdot 6 \mathrm{H}_{2} \mathrm{O}, \mathrm{NaN}_{3}$ and DDQ produced quantitative yield of cinnamaldehyde.

20 Reaction of cinnamyl alcohol (1a) with DDQ (1.2 equiv.), $\mathrm{TMSN}_{3}$ (1.5 equiv.) and $\mathrm{Cu}\left(\mathrm{ClO}_{4}\right)_{2} \cdot 6 \mathrm{H}_{2} \mathrm{O}(5 \mathrm{~mol} \%)$ furnished cinnamonitrile in major amounts (85-90\%), along with a minor amount of aldehyde $(10 \%)$. To circumvent this problem, 2.2 equiv. of DDQ was employed which furnished cinnamonitrile (2a) exclusively in good yield $(99 \%)$.

21 This reaction has produced the mixture of $E$ and $Z$ diastereomers in the ratio of 8.9 : 1.1 (based on ${ }^{1} \mathrm{H}$ NMR).

22 K. Nishiyama, M. Oba and A. Watanabe, Tetrahedron, 1987, 43, 693.

23 K. Banert, C. Berndt, S. Firdous, M. Hagedorn, Y.-H. Joo, T. Ruffer and H. Lang, Angew. Chem., Int. Ed., 2010, 49, 10206.

24 G. I. Koldobskii, V. A. Ostrovskii and B. V. Gidaspov, Russ. Chem. Rev., 1978, 47, 1084. 